\title{
Analysis of the Influence of Service Quality, Facilities and Value Rates on Patient Interest through Inpatient Satisfaction at Islam Malahayati Hospital
}

\author{
Saparuddin Siregar ${ }^{1}$, Yenni Samri Juliati Nst' ${ }^{2}$, Rafia Hafni Harahap ${ }^{3}$ \\ 1,2,3 Universitas Islam Negeri Sumatera Utara, Indonesia \\ saparuddin@uinsu.ac.id,yenni.samri@uinsu.ac.id,fiahafni@gmail.com
}

\begin{abstract}
This study aims to analyze the effect of service quality, facilities and tariff rates on patient interest through inpatient satisfaction at Islam Malahayati Hospital Medan. This research method uses a quantitative approach with path analysis and uses the assistance of the SPSS program version 20.0. This study used a questionnaire with a sample of 56 respondents with data collection. The results of the study based on a partial test show that the Service Quality variable has a positive and significant effect on Patient Satisfaction at Islam Malahayati Hospital Medan, and the tariff value variable has a positive and significant effect on patient satisfaction and the Facility variable has a positive and significant effect on Patient Satisfaction. Then service quality has a positive and significant effect on patient interest in Malahayati Hospital, and service facilities have a positive and significant effect on patient interest. The tariff value has a positive and significant effect on patient interest and patient satisfaction has a positive and significant effect on patient interest. While the results of the study based on the simultaneous test showed that the variables of Service Quality, Facilities and Value Rates had a positive and significant effect on patient satisfaction through patient interest. The implications of this study indicate that through good service to patients it will be able to increase patient satisfaction so that it has an impact on patient satisfaction and patient interest. Facilities that have been determined by the hospital can be reached by the patient and can increase patient visits as well as the value of the rate can be measured through benefits or from what has been provided by the hospital if the facilities provided by the hospital are complete and can fulfill the patient's wishes, it will have a good impact on the development and success of the hospital.
\end{abstract}

\section{Keywords}

service quality; facilities and value rates; patient interest; patient satisfaction

\section{Introduction}

Hospitals established and managed by private parties. The advantages possessed by private hospitals are the provision of complete facilities for patients, the quality of service that is higher quality when compared to government hospitals, service to patients that is good, friendly, not slow, fast and the attitude of professional medical personnel in handling patients.

Within the hospital itself, there are complex organizations, each of which requires a budget. Hospital service activities are also closely related to things such as services, facilities, finances, patient satisfaction, management and community conditions. And in the budget principle rules, there are budget efficiency, effectiveness, transparency, and accountability as a form of accountability for the management system (Rikomah, 2017). 
Hospital is a health service provider that is the choice of the community, especially the middle to upper class, therefore the tariff set must be affordable according to the economic capacity of the local community. According to Wahyuni and Fauzia (2020) Hospitals must have qualified medical personnel and be able to serve the community professionally. Human development can also be interpreted as building a person's ability through improving the level of health, knowledge or education and skills (Suhandojo in Adiwijaya et al, 2018). The hope of the hospital community can provide health services that are easy, cheap, and efficient. Perceived rates greatly influence patient satisfaction. The third factor after service quality and tariff is facilities. The number of health service providers requires consumers to be more critical in choosing which hospital services to use. Medical service support facilities are one of the factors being considered. Improvement of hospital facilities and infrastructure also needs to be done to prevent the emergence of obstacles in the provision of quality health services. With the improvement of facilities and infrastructure, it is hoped that the hospital will be able to anticipate various technical problems in the field faced by patients in obtaining quality services. Efforts aimed at planning, tariff setting, promoting satisfying the needs of both existing and potential buyers mean that marketing activities are carried out not solely to sell goods or services but to satisfy the needs and desires of patients.Providing the best quality service is not something easy for hospital managers because the services provided by the hospital are related to the quality of life of its patients so that if there is an error in medical action it can have a negative impact on the patient. These impacts can include the patient's illness getting worse, disability and even death (John, 1992).

Data on the number of inpatients at Islam Malahayati Hospital from January 2015 to June 2019 are as follows:

Table 1. Table of Data on the Number of Inpatients at Islam Malahayati Hospital

\begin{tabular}{|c|c|c|c|}
\hline \multirow{2}{*}{ Year } & \multicolumn{3}{|c|}{ Number of Patients } \\
\cline { 2 - 4 } & New & Long & Total \\
\hline 2015 & 5.102 & 15.728 & 20.830 \\
\hline 2016 & 3.941 & 15.919 & 19.860 \\
\hline 2017 & 4.350 & 16.097 & 20.447 \\
\hline 2018 & 4.254 & 15.436 & 19.690 \\
\hline 2019 & 6.394 & 13.976 & 20.370 \\
\hline Amount & 24.041 & 77.156 & 118.787 \\
\hline
\end{tabular}

Source: Islam Malahayati Hospital archive data, 2015 - 2019

From the data on the number of IMH (Islam Malahayati Hospital) patients, it can be seen that the number of patients fluctuates. This shows changes in both the increase and decrease in the number of patients, both for first-time arrivals and old patients at IMH.

Based on table 1 above, the data on the number of new patients and length of hospitalization in IMH fluctuate. From 2015 to 2019 the number of new patients has fluctuated. In 2015 the number of new patients was 5,102 people, then in 2016 the new patients decreased to 3,941 people, then in 2017 new patients increased to 4,350 people. In 2018 the number of patients decreased to 4,254, then in 2019 new patients experienced a very significant increase to 24,041 . This shows changes in both the increase and decrease in the number of patients, both for first-time arrivals and old patients at IMH.

Meanwhile, the quality of service at the hospital really determines the patient's satisfaction at the time of treatment, both inpatient and non-inpatient. From the description above, it is conveyed that services can provide satisfaction for patients if expectations are 
the same as the reality received by patients. In this regard, it is very important to conduct research on the quality of service in a hospital.

Table 2. Services and Facilities of Islam Malahayati Hospital

\begin{tabular}{|c|l|c|c|c|c|c|}
\hline No. & Services and Facilities & $\mathbf{2 0 1 5}$ & $\mathbf{2 0 1 6}$ & $\mathbf{2 0 1 7}$ & $\mathbf{2 0 1 8}$ & $\mathbf{2 0 1 9}$ \\
\hline 1 & $\begin{array}{l}\text { Ease of patient registration } \\
\text { process }\end{array}$ & $15 \%$ & $10 \%$ & $8 \%$ & $6 \%$ & $3 \%$ \\
\hline 2 & environmental Hygiene & $13 \%$ & $7 \%$ & $8 \%$ & $3 \%$ & $1 \%$ \\
\hline 3 & $\begin{array}{l}\text { Attention doctors, nurses } \\
\text { individually to patients }\end{array}$ & $10 \%$ & $10 \%$ & $7 \%$ & $3 \%$ & $2 \%$ \\
\hline 4 & The patient's diet & $16 \%$ & $12 \%$ & $14 \%$ & $3 \%$ & $3 \%$ \\
\hline 5 & $\begin{array}{l}\text { Schedule accuracy, } \\
\text { examinations by doctors } \\
\text { and nurses }\end{array}$ & $2 \%$ & $4 \%$ & $7 \%$ & $8 \%$ & $5 \%$ \\
\hline 6 & $\begin{array}{l}\text { The ability of doctors and } \\
\text { nurses to handle patient } \\
\text { complaints }\end{array}$ & $8 \%$ & $9 \%$ & $6 \%$ & $6 \%$ & $4 \%$ \\
\hline 7 & The nurse is not friendly & $18 \%$ & $12 \%$ & $10 \%$ & $7 \%$ & $5 \%$ \\
\hline 8 & Bathroom cleanliness & $8 \%$ & $7 \%$ & $7 \%$ & $5 \%$ & $5 \%$ \\
\hline \multicolumn{1}{|c|}{ Amount } & 90 & $90 \%$ & $71 \%$ & $67 \%$ & $41 \%$ \\
\hline
\end{tabular}

Source: Islam Malahayati Hospital archive data, 2015 - 2019

Based on table 2 above, the data on the number of service quality and facilities at Malahayati Islamic Hospital has fluctuated. From 2015 to 2019, the ease of the patient registration process has increased every year. From 2015 to 2019, the environmental cleanliness of the IMH has decreased. In 2015 to 2019 doctor's attentionindividual nurses to patients decreased from 2017. From 2015 to 2019 the patient's diet decreased. From 2015 to 2019, the accuracy of schedules, examinations by doctors and nurses has fluctuated. From 2015 to 2019 The ability of doctors and nurses to handle patient complaints has fluctuated. From 2015-2019 the nurses were less friendly and bathroom cleanliness had decreased.

The table above shows the increasing number of complaints or complaints of inpatients regarding the performance of IMH services. This if allowed to reduce the satisfaction and interest in buying (the desire to use services again) inpatients, which in turn has a negative impact on the progress and development of the hospital.

\section{Review of Literature}

\subsection{Service quality}

In the health service industry, service quality is one of the business strategies that emphasizes meeting consumer desires. According to Goeth and Davis, as quoted by Tjiptono, quality is a dynamic condition related to products, services, people, environmental processes that meet or exceed expectations (Tjiptono, 2000).

According to Ibrahim, describing quality from producer observations summarized as quality is a basic business strategy that produces goods and services that meet the needs and satisfaction of internal and external consumers, explicitly and implicitly. This strategy uses all the capabilities of the company's management, capital, technology, equipment, materials, systems and human resources to produce value-added goods or services for the benefit of society as well as to provide benefits to shareholders" (Ibrahim, 1997). 


\subsection{Amenities}

In simple terms, what is meant by facility is a physical facility that can process an input into the desired output. While the process can be said as a service activity using a facility. For example, the production process, trade process and so on (Zaharuddin, 2006).

Facilities are physical resources that must exist before a service can be offered to consumers (Tjiptono, 2001). Facilities can be in the form of something that makes it easier for consumers to get satisfaction. Because a form of service cannot be seen, cannot be smelled and cannot be felt, the physical aspect becomes important as a measure of service.

\subsection{Fare Value}

Tariff or cost is the value of a number of inputs (factors of production) used to produce a product (output) (Munawar, 2003). Hospital rates are an aspect of which private and government hospitals are concerned. Each hospital will set service rates according to their respective missions. However, there are relatively similar considerations in determining hospital rates, namely obtaining sufficient revenue for hospital operations, both from service users and from other sources. There are hospitals that only need revenue to cover operational costs, there are those that only need funds for consumables, and there are hospitals that need funds for all kinds of expenses, including shareholder income.

\subsection{Patient Interests}

According to Sutantio's research, buying interest is the possibility that the buyer is interested in buying a product (Sutantio, 2004). Meanwhile, according to Howard's research in Sutantio, he defines invention to buy as a statement relating to the mind that reflects the buyer's plan to buy a certain brand within a certain period of time (Sutantio, 2004). Purchase interest is the tendency of consumers to buy a brand or take action related to purchases which is measured by the level of possibility of consumers making a purchase (Henry, 2001).

\subsection{Patient Satisfaction}

According to Kotler and Keller, consumer satisfaction is a feeling of pleasure or disappointment for someone who appears after comparing the performance or product results that are thought of against the expected performance or original (Kotler, Philip \& Keller, 2016). Meanwhile, according to Lupiyoadi, customer satisfaction is defined as the customer response to the mismatch between the previous level of importance and the actual performance it feels after use (Rambat Lupiyoadi, 2013). Consumers experience various levels of satisfaction or dissatisfaction after experiencing each service according to the extent to which their expectations are met or exceeded. Since contentment is an emotional state, their post-purchase reactions can be anger, dissatisfaction, irritation, neutrality, excitement or pleasure (Lovelock, Christopher \& Lauren K. Wright, 2007).

\section{Research Methods}

This research is a quantitative research. This study was analyzed using path analysis. The data used in this study are secondary data from the data reports of the Malahayati Islamic hospital in Medan from 2015 to 2019. The population of this study is the Malahayati Islamic hospital. The research sample selected was 56 respondents. 


\section{Results and Discussion}

\subsection{Validity and Reliability Test}

a. Validity test

From the list of statements contained in the research questionnaire consisting of 25 statements on service quality variables, 6 statements on facility variables, 5 statements on tariff (price) value variables, 6 statements on interest variables, and 6 statements on patient satisfaction variables towards Islam Malhayati Hospital Medan.

\section{Service Quality Variable}

The following are the results of the validity test for the service quality variable (X1), namely:

Table 3. Service Quality Variable (X1)

\begin{tabular}{|c|c|c|c|}
\hline No. Item & $\mathbf{r}_{\mathbf{x y}}$ & $\mathbf{r}_{\text {table }}$ & Information \\
\hline ITEM_1 & 0.429 & 0.2632 & Valid \\
\hline ITEM_2 & 0.338 & 0.2632 & Valid \\
\hline ITEM_3 & 0.421 & 0.2632 & Valid \\
\hline ITEM_4 & 0.350 & 0.2632 & Valid \\
\hline ITEM_5 & 0.306 & 0.2632 & Valid \\
\hline ITEM_6 & 0.504 & 0.2632 & Valid \\
\hline ITEM_7 & 0.530 & 0.2632 & Valid \\
\hline ITEM_8 & 0.380 & 0.2632 & Valid \\
\hline ITEM_9 & 0.431 & 0.2632 & Valid \\
\hline ITEM_10 & 0.384 & 0.2632 & Valid \\
\hline ITEM_11 & 0.447 & 0.2632 & Valid \\
\hline ITEM_12 & 0.517 & 0.2632 & Valid \\
\hline ITEM_13 & 0.452 & 0.2632 & Valid \\
\hline ITEM_14 & 0.545 & 0.2632 & Valid \\
\hline ITEM_15 & 0.518 & 0.2632 & Valid \\
\hline ITEM_16 & 0.512 & 0.2632 & Valid \\
\hline ITEM_17 & 0.457 & 0.2632 & Valid \\
\hline ITEM_18 & 0.291 & 0.2632 & Valid \\
\hline ITEM_19 & 0.299 & 0.2632 & Valid \\
\hline ITEM_20 & 0.596 & 0.2632 & Valid \\
\hline ITEM_21 & 0.279 & 0.2632 & Valid \\
\hline ITEM_22 & 0.351 & 0.2632 & Valid \\
\hline ITEM_23 & 0.359 & 0.2632 & Valid \\
\hline ITEM_24 & 0.360 & 0.2632 & Valid \\
\hline ITEM_25 & 0.572 & 0.2632 & Valid \\
\hline
\end{tabular}

Based on the table above, it can be seen that all statement items related to service quality variables (X1) is valid. 


\section{Facility Variable}

The following are the results of the validity test for the facility variable (X2), that is:

Table 4. Results of the Facility Variable Validity Test (X2)

\begin{tabular}{|l|c|c|c|}
\hline No. Item & $\mathbf{r}_{\mathbf{x y}}$ & $\mathbf{r}_{\text {table }}$ & Information \\
\hline ITEM 1 & 0.842 & 0.2632 & Valid \\
\hline ITEM 2 & 0.880 & 0.2632 & Valid \\
\hline ITEM 3 & 0.823 & 0.2632 & Valid \\
\hline ITEM 4 & 0.805 & 0.2632 & Valid \\
\hline ITEM 5 & 0.659 & 0.2632 & Valid \\
\hline ITEM 6 & 0.487 & 0.2632 & Valid \\
\hline
\end{tabular}

Based on the table above, it can be seen that all statement items on the facility variable $(\mathrm{X} 2)$ is valid.

\section{Tariff Value Variable}

The following are the results of the validity test for the variable tariff rates (X3);

Table 5. Result of Validity Test of Variable Value Rates (X3)

\begin{tabular}{|l|c|c|c|}
\hline No. Item & $\mathbf{r}_{\mathbf{x y}}$ & $\mathbf{r}_{\text {table }}$ & Information \\
\hline ITEM 1 & 0.667 & 0.2632 & Valid \\
\hline ITEM 2 & 0.706 & 0.2632 & Valid \\
\hline ITEM 3 & 0.499 & 0.2632 & Valid \\
\hline ITEM 4 & 0.743 & 0.2632 & Valid \\
\hline ITEM 5 & 0.544 & 0.2632 & Valid \\
\hline
\end{tabular}

Based on the table above, it can be seen that all statement items on the variable rate (X3) is valid.

\section{Interests Variable}

The following are the results of the validity test for the variable of interest (Y);

Table 6. Results of the Validity Test of Interest Variables (Y)

\begin{tabular}{|l|c|c|c|}
\hline No. Item & $\mathbf{r}_{\mathbf{x y}}$ & $\mathbf{r}_{\text {table }}$ & Information \\
\hline ITEM 1 & 0.636 & 0.2632 & Valid \\
\hline ITEM 2 & 0.772 & 0.2632 & Valid \\
\hline ITEM 3 & 0.485 & 0.2632 & Valid \\
\hline ITEM 4 & 0.619 & 0.2632 & Valid \\
\hline ITEM 5 & 0.636 & 0.2632 & Valid \\
\hline ITEM 6 & 0.772 & 0.2632 & Valid \\
\hline
\end{tabular}

Based on the table above, it can be seen that all the statement items on the interest variable $(\mathrm{Y})$ is valid.

\section{Satisfaction Variable}

The following are the results of the validity test for the satisfaction variable $(\mathrm{Z})$;

Table 7. Results of the Validity Test of the Satisfaction Variable $(\mathrm{Z})$

\begin{tabular}{|l|c|c|c|}
\hline No. Item & $\mathbf{r}_{\mathbf{x y}}$ & $\mathbf{r}_{\text {table }}$ & Information \\
\hline ITEM 1 & 0.748 & 0.2632 & Valid \\
\hline ITEM 2 & 0.760 & 0.2632 & Valid \\
\hline
\end{tabular}




\begin{tabular}{|l|l|l|l|}
\hline ITEM 3 & 0.752 & 0.2632 & Valid \\
\hline ITEM 4 & 0.608 & 0.2632 & Valid \\
\hline ITEM 5 & 0.842 & 0.2632 & Valid \\
\hline ITEM 6 & 0.610 & 0.2632 & Valid \\
\hline
\end{tabular}

Based on the table above, it can be seen that all statement items on the satisfaction variable $(\mathrm{Z})$ is valid.

\section{b. Reliability Test}

In this study, the reliability test was carried out with an internal consistency. The results of this test will reflect whether or not a research instrument can be trusted, based on the level of accuracy and stability of a measuring instrument. The level of reliability used with Alpha Cronbach is measured from a scale of 0 to 1 . The results of the reliability test on the variables of this study are as follows:

Tabel 8. Research Variable Reliability Test Results

Reliability Statistics

\begin{tabular}{|l|c|c|c|}
\hline \multicolumn{1}{|c|}{ Variable Name } & $\begin{array}{c}\text { Cronbach's } \\
\text { Alpha }\end{array}$ & N of Items & Level of reliability \\
\hline Quality of Service $\left(\mathbf{X}_{\mathbf{1}}\right)$ & 0.803 & 25 & Very Reliable \\
\hline Facilities $\left(\mathbf{X}_{\mathbf{2}}\right)$ & 0.848 & 6 & Very Reliable \\
\hline Fare value $\left(\mathbf{X}_{\mathbf{3}}\right)$ & 0.632 & 5 & Reliable \\
\hline Interests $(\mathbf{Y})$ & 0.769 & 6 & Reliable \\
\hline Satisfaction $(\mathbf{Z})$ & 0.818 & 6 & Very Reliable \\
\hline
\end{tabular}

Based on the output using SPSS Version 21.0 for Windows in the table above the values are obtained Cronbach's Alpha in each of the variables studied were stated to be at a very reliable and reliable level.

\subsection{Classic Assumption Test}

\section{a. Normality test}

In this study, the normality test used the Kolmogorov-Smirnov Test. The following is presented the results of the Kolmogorov-Smirnov Test in the table below:

Table 9. Normality Test Results

One-Sample Kolmogorov-Smirnov Test

\begin{tabular}{|l|l|r|r|}
\hline \multicolumn{2}{|l|}{} & \multicolumn{1}{|c|}{$\begin{array}{c}\text { Unstandardized } \\
\text { Residual }\end{array}$} & $\begin{array}{c}\text { Unstandardized } \\
\text { Residual }\end{array}$ \\
\hline $\mathrm{N}$ & 56 & 56 \\
\hline Normal Parameters & Mean & .0000000 & .0000000 \\
\cline { 2 - 4 } & $\begin{array}{l}\text { Std. } \\
\text { Deviation }\end{array}$ & 2.87432782 & 2.28473070 \\
\hline $\begin{array}{l}\text { Most Extreme } \\
\text { Differences }\end{array}$ & Absolute & .128 & .093 \\
\cline { 2 - 4 } & Positive & .077 & .090 \\
\cline { 2 - 4 } & Negative & -.128 & -.093 \\
\hline Test Statistic & & .128 & .093 \\
\hline Asymp. Sig. (2-tailed) & & $.024^{\mathrm{c}}$ & $.200^{\mathrm{c}, \mathrm{d}}$ \\
\hline
\end{tabular}

a. Test distribution is Normal.

b. Calculated from data.

c. Lilliefors Significance Correction.

d. This is a lower bound of the true significance. 
Based on the results of processing using SPSS Version 21.0 for Windows, it can be concluded that all variables used in this study have a significance level above 0,05 . This can be seen with the Asymp results. Sig. (2-tailed) of 0,200>0,05. This means that the data used in this study have a normal distribution and indicate that the regression model is feasible because it meets the assumption of normality.

\section{b. Heteroscedasticity Test}

In this study, to test the occurrence of heteroscedasticity, graphical analysis can be used to detect the presence or absence of a heteroscedasticity symptom by looking at the presence or absence of a certain pattern in the scatterplot between the independent variable (ZPRED) and its residual (SRESID). The basis for this graphical analysis is that if there is a certain pattern such as dots that form a certain regular pattern, it indicates heteroscedasticity. If there is no clear pattern, as well as dots that spread above and below zero on the $\mathrm{Y}$ axis, it indicates that heteroscedasticity does not occur.

\section{c. Multicollinearity Test}

The multicollinearity test in this study aims to test whether the regression model found in this study has a correlation between the independent variables or not. The output results of SPSS Version 21.0 for Windows from this multicolinearity test can be seen in the following table:

Table 10. Multicollinearity Test Results

\begin{tabular}{|c|c|c|c|c|c|c|c|c|}
\hline & \multirow[t]{2}{*}{ Model } & \multicolumn{2}{|c|}{$\begin{array}{l}\text { Unstandardized } \\
\text { Coefficients }\end{array}$} & \multirow{2}{*}{$\begin{array}{c}\begin{array}{c}\text { Standardized } \\
\text { Coefficients }\end{array} \\
\text { Beta }\end{array}$} & \multirow[t]{2}{*}{$\mathrm{T}$} & \multirow[t]{2}{*}{ Sig. } & \multicolumn{2}{|c|}{$\begin{array}{l}\text { Collinearity } \\
\text { Statistics }\end{array}$} \\
\hline & & B & Std. Error & & & & Tolerance & VIF \\
\hline \multirow[t]{4}{*}{1} & (Constant) & .124 & 5.660 & & .022 & .983 & & \\
\hline & X-1 & .026 & .059 & .054 & .445 & .658 & .797 & 1.254 \\
\hline & $X-2$ & .421 & .105 & .473 & 4.013 & .000 & .840 & 1.190 \\
\hline & X-3 & .542 & .161 & .376 & 3.371 & .001 & .939 & 1.065 \\
\hline
\end{tabular}

a. Dependent Variable: Y,Z

From the results of the multicollinearity test using SPSS Version 21.0 for Windows, the coefficients contained in the output can be seen that the VIF value of the service quality variable $\left(\mathbf{X}_{1}\right)=1.254$; facility variable $\left(\mathbf{X}_{2}\right)=1.190$; variable rate rate $\left(\mathbf{X}_{\mathbf{3}}\right)=1.065$. While the Tolerance value of the service quality variable $\left(\mathbf{X}_{1}\right)=0.797$; facility variable $\left(\mathbf{X}_{2}\right)=$ 0.840 ; variable rate rate $\left(\mathbf{X}_{3}\right)=0.939$. This is indicated by the acquisition of the Variance Inflation Factors (VIF) value of each variable under study which scores below 10 and a Tolerance value greater than 0.1 , it can be concluded that the results of all research variables from the regression model do not have multicollinearity symptoms.

\subsection{Hypothesis Testing}

\section{a. Path Analysis of Equation I (Indirect Effect)}

The first substructure equation in this research model is to determine and analyze the positive and significant effects of $\mathbf{X}_{\mathbf{1}}, \mathbf{X}_{\mathbf{2}}$ and $\mathbf{X}_{\mathbf{3}}$ on $\mathbf{Z}$. With the following equation:

$$
\mathrm{Z}=\mathrm{a}+\beta_{1} X_{1}+\beta_{2} X_{2}+\beta_{3} X_{3}+\varepsilon
$$

Based on the I substructure equation above using SPSS Version 21.0 for Windows, the results can be seen as follows: 
Table 11. Model Summary ${ }^{\mathrm{b}}$

\begin{tabular}{|l|r|r|r|r|r|r|r|r|r|}
\hline \multirow{2}{*}{ Model } & \multirow{2}{*}{$\mathrm{R}$} & \multirow{2}{*}{ R Square } & \multirow{2}{*}{$\begin{array}{l}\text { Adjusted } \\
\text { R Square }\end{array}$} & $\begin{array}{l}\text { Std. Error of } \\
\text { the Estimate }\end{array}$ & \multicolumn{6}{|c|}{$\begin{array}{c}\text { R Square } \\
\text { Change }\end{array}$} & F Change & df1 & df2 & $\begin{array}{c}\text { Sig. F } \\
\text { Change }\end{array}$ \\
\hline 1 & $.798^{\mathrm{a}}$ & .637 & .617 & 2.34971 & .637 & 30.482 & 3 & 52 & .000 \\
\hline
\end{tabular}

a. Predictors: (Constant), X-3, X-2, X-1

b. Dependent Variable: Z

Table 12. ANOVA ${ }^{\mathrm{a}}$

\begin{tabular}{|l|l|r|r|r|c|c|}
\hline \multicolumn{2}{|c|}{ Model } & $\begin{array}{c}\text { Sum of } \\
\text { Squares }\end{array}$ & df & $\begin{array}{c}\text { Mean } \\
\text { Square }\end{array}$ & F & Sig. \\
\hline \multirow{2}{*}{1} & Regression & 504.882 & 3 & 168.294 & 30.482 & $.000^{\mathrm{b}}$ \\
\cline { 2 - 7 } & Residual & 287.100 & 52 & 5.521 & & \\
\cline { 2 - 7 } & Total & 791.982 & 55 & & & \\
\hline
\end{tabular}

a. Dependent Variable: Z

b. Predictors: (Constant), X-3, X-2, X-1

In the attachment above, you can see the Sig. on the table ANOVA ${ }^{\mathrm{a}}$ has a Sig value. is equal to 0.000 or smaller than the probability value of 0.05 ( $\operatorname{sig} 0.000<0.050$ ), then $\mathrm{H} 0$ is rejected and $\mathrm{Ha}$ is accepted. This means that the regression coefficient built is significant. So, for variables $\mathbf{X}_{\mathbf{1}}, \mathbf{X}_{\mathbf{2}}$ and $\mathbf{X}_{\mathbf{3}}$ simultaneously and significantly influence $\mathbf{Z}$. Simultaneously the variables $\mathbf{X}_{\mathbf{1}}, \mathbf{X}_{\mathbf{2}}$ and $\mathbf{X}_{\mathbf{3}}$ have a contribution of $63.7 \%$ (it can be seen that the value of R Square in the table Model Summary ${ }^{\mathbf{b}}$ ) which explains the changes that occur in variable $\mathbf{Z}$ while the remaining $36.3 \%$ is explained by other variables outside the built model.

On the table ANOVA ${ }^{\text {a }}$ It can be seen that simultaneously the independent variables have a significant influence on the $\mathbf{Z}$ variable as indicated by the Sig. $0,000<\alpha 5 \%$ (where $\mathrm{H}_{0}$ is rejected and $\mathrm{H}_{\mathrm{a}}$ is accepted or in other words, the $\mathrm{F}$ statistical test that is carried out is significant).

Table 13. Coefficients ${ }^{\mathrm{a}}$

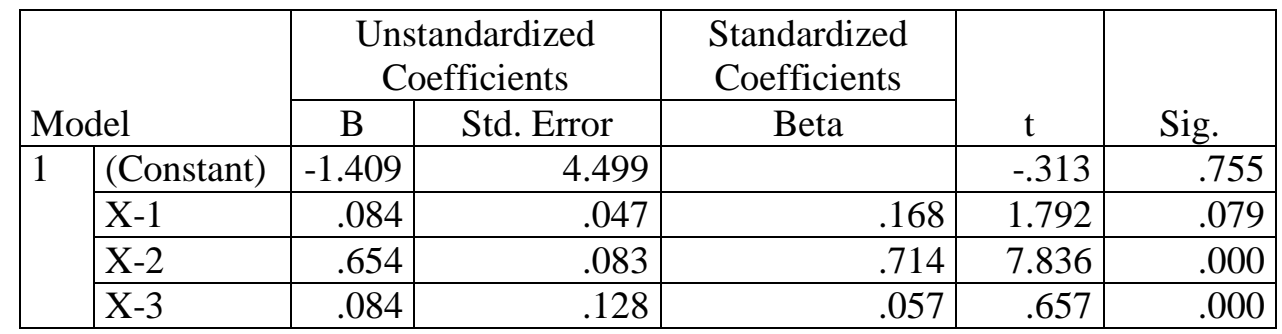

a. Dependent Variable: Z

On the table Coefficients ${ }^{\mathrm{a}}$ variables $\mathbf{X}_{\mathbf{1}}, \mathbf{X}_{\mathbf{2}}$ and $\mathbf{X}_{\mathbf{3}}$ simultaneously to variable $\mathbf{Z}$ which is intended to test the significance of the constant and the dependent variable.

Hypothesis:

Ha: Variable $\mathbf{X}_{\mathbf{1}}, \mathbf{X}_{\mathbf{2}}$ and $\mathbf{X}_{\mathbf{3}}$ simultaneously and significantly influence the variable $\mathbf{Z}$

On the coefficient, the $t$ test (partial) shows that the variables $\mathbf{X}_{\mathbf{1}}, \mathbf{X}_{\mathbf{2}}$ and $\mathbf{X}_{\mathbf{3}}$ statistically have a significant effect on variable $\mathbf{Z}$ as indicated by the Sig value $<\alpha 5 \%$, namely $0.079 ; 0,000$ and 0,000 . The structural equation looks like this:

$\mathrm{Z}=-\mathbf{1 , 4 0 9}+\mathbf{0 , 0 8 4} X_{1}+\mathbf{0 , 6 5 4} X_{2}+0,084 X_{3}+\varepsilon$ 


\section{b. Path Analysis of Equation II (Direct Effect)}

The second substructure equation in this research model is to determine and analyze the positive and significant effects of $\mathbf{X}_{\mathbf{1}}, \mathbf{X}_{\mathbf{3}}$ and $\mathbf{Z}$ on $\mathbf{Y}$.With the following equation: $\mathrm{Y}=\mathbf{a}+\beta_{1} X_{1}+\beta_{3} X_{3}+\beta_{Z} Z_{z}+\varepsilon$

Based on the above equation using SPSS Version 21.0 for Windows, the results can be seen as follows:

Table 14. Model Summary ${ }^{\mathrm{b}}$

\begin{tabular}{|l|r|r|r|r|r|r|r|r|r|}
\hline \multirow{2}{*}{ Model } & \multirow{2}{*}{$\mathrm{R}$} & \multirow{2}{*}{ R Square } & \multirow{2}{*}{$\begin{array}{l}\text { Adjusted } \\
\text { R Square }\end{array}$} & $\begin{array}{l}\text { Std. Error of } \\
\text { the Estimate }\end{array}$ & $\begin{array}{c}\text { R Square } \\
\text { Change }\end{array}$ & F Change & df1 & df2 & $\begin{array}{c}\text { Sig. F } \\
\text { Change }\end{array}$ \\
\hline 1 & $.940^{\mathrm{a}}$ & .884 & .882 & 1.980 & .884 & 110.804 & 3 & 52 & .000 \\
\hline
\end{tabular}

a. Predictors: (Constant), X-3, X-1, Z

b. Dependent Variable: Y

Table 15. ANOVA ${ }^{\mathrm{a}}$

\begin{tabular}{|l|l|r|r|r|c|c|}
\hline \multicolumn{2}{|c|}{ Model } & $\begin{array}{c}\text { Sum of } \\
\text { Squares }\end{array}$ & df & $\begin{array}{c}\text { Mean } \\
\text { Square }\end{array}$ & F & Sig. \\
\hline \multirow{2}{*}{1} & Regression & 287.917 & 3 & 95.972 & 110.804 & $.000^{\mathrm{b}}$ \\
\cline { 2 - 7 } & Residual & 461.922 & 52 & 8.883 & & \\
\cline { 2 - 7 } & Total & 749.839 & 55 & & & \\
\hline
\end{tabular}

a. Dependent Variable: Y

b. Predictors: (Constant), X-3, X-1, Z

In the attachment above, you can see the Sig. on the table ANOVA ${ }^{\mathrm{a}}$ has a Sig value. is equal to 0.000 or smaller than the probability value of 0.05 ( $\mathrm{sig} 0.000<0.050$ ), then $\mathrm{H} 0$ is rejected and $\mathrm{Ha}$ is accepted. This means that the regression coefficient built is significant. So, for variables $\mathbf{X}_{\mathbf{1}}, \mathbf{X}_{\mathbf{3}}$ and $\mathbf{Z}$ have a simultaneous and significant effect on $\mathbf{Y}$. Simultaneously, the variables $\mathbf{X}_{\mathbf{1}}, \mathbf{X}_{\mathbf{3}}$ and $\mathbf{Z}$ have a contribution of $88.4 \%$ (it can be seen that the value of R Square in the table Model Summary ${ }^{\mathbf{b}}$ ) which explains the changes that occur in the $\mathbf{Y}$ variable while the remaining $11.6 .3 \%$ is explained by other variables outside the built model.

On the table ANOVA ${ }^{\text {a }}$ It can be seen that simultaneously the independent variables have a significant influence on the $\mathbf{Y}$ variable as indicated by the Sig. $0,000<\alpha 5 \%$ (where $\mathrm{HO}$ is rejected and $\mathrm{Ha}$ is accepted or in other words, the F statistical test that is carried out is significant)

Table 16. Coefficients ${ }^{\mathrm{a}}$

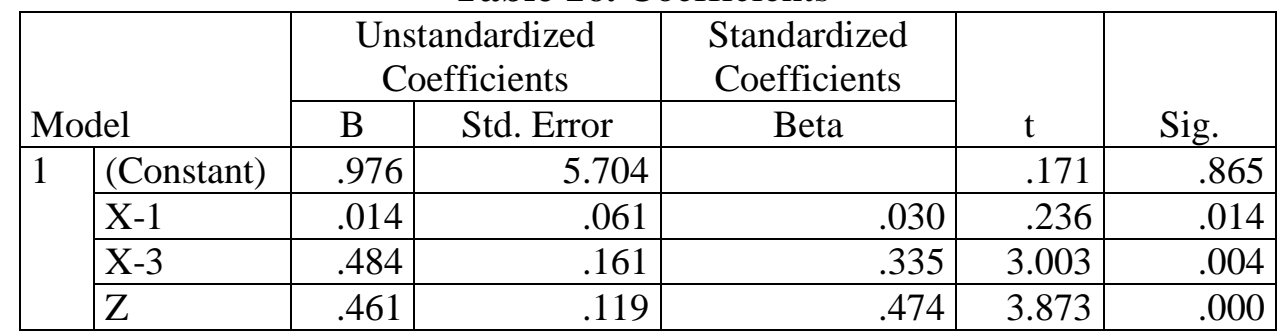

a. Dependent Variable: Y

On the table Coefficientsa variables $\mathbf{X}_{\mathbf{1}}, \mathbf{X}_{\mathbf{3}}$ and $\mathbf{Z}$ simultaneously to variable $\mathbf{Y}$ which is intended to test the significance of the constant and the dependent variable. 


\section{Hypothesis:}

Ha: Variable $\mathbf{X}_{\mathbf{1}}, \mathbf{X}_{\mathbf{3}}$ and $\mathbf{Z}$ have a simultaneous and significant effect on variable $\mathbf{Y}$

On the coefficient, the $t$ test (partial) shows that the variable $\mathbf{X}_{\mathbf{1}}, \mathbf{X}_{\mathbf{3}}$ and $\mathbf{Z}$ statistically have a significant effect on variable $\mathrm{Y}$ as indicated by the value of each $\mathrm{Sig}<\alpha$ $5 \%$, namely $0.014 ; 0.004$ and 0.000 . The structural equation looks like this:

$\mathrm{Y}=0,976+0,014 X_{1}+0,484 X_{3}+0,461 Z+\varepsilon$

From the above discussion, the results are variable $\mathbf{X 1}, \mathbf{X} 2, \mathbf{X 3}$ and $\mathbf{Z}$ able to explain the diversity in variables Y88.4\% while the remaining $11.6 \%$ can be explained by other variables outside the model. It can be seen from the Sig. equal to $0,000<\alpha 0.05$. In the $t$ test (partial), it turns out that the variables $\mathrm{X} 1, \mathrm{X} 2, \mathrm{X} 3$ and $\mathrm{Z}$ statistically significantly affect the Y variable (where the Sig value, is $0.005<\alpha 5 \%$ ).

Table 17. Recapitulation of Path Analysis Test Results (Path Analysis)

\begin{tabular}{|c|c|}
\hline Information & Weight \\
\hline $\begin{array}{ll}\text { 1. } & \text { The direct effect of } \mathbf{X} \mathbf{1} \text { on } \mathbf{Y} \\
\text { 2. } & \text { Indirect effect } \mathrm{X} 1 \rightarrow \mathbf{Z} \text { against } \mathbf{Y} \\
\text { 3. } & \text { The total effect of } \mathbf{X} \mathbf{1} \text { on } \mathbf{Y}\end{array}$ & $\begin{array}{l}=0.014 \\
=0.084 \times 0.461 \\
=0.5412\end{array}$ \\
\hline $\begin{array}{l}\text { 4. The direct effect of } \mathbf{X}_{2} \text { on } \mathbf{Y} \\
\text { 5. The indirect effect of } \mathbf{X}_{2} \rightarrow \mathbf{Z} \text { against } \mathbf{Y} \\
\text { 6. The total effect of } \mathbf{X}_{2} \text { on } Y\end{array}$ & $\begin{array}{l}=0.484 \\
=0.654 \times 0.461 \\
=0.1459\end{array}$ \\
\hline $\begin{array}{ll}\text { 7. } & \text { The direct effect of } \mathbf{X}_{\mathbf{3}} \text { on } \mathbf{Y} \\
\text { 8. } & \text { The indirect effect of } \mathbf{X}_{\mathbf{3}} \rightarrow \mathbf{Z} \text { against } \mathbf{Y} \\
\text { 9. } & \text { The total effect of } \mathbf{X}_{\mathbf{3}} \text { on } \mathbf{Y}\end{array}$ & $\begin{array}{l}=0.484 \\
=0.084 \times 0.461 \\
=0.1874\end{array}$ \\
\hline 10. Direct influence of $\mathbf{Z}$ on $\mathbf{Y}$ & $=0.461$ \\
\hline
\end{tabular}

From the above calculations, which significantly affects the variable $\mathrm{Y}$ is the variable $\mathrm{X} 1, \mathrm{X} 2, \mathrm{X3}$, and $\mathrm{Z}$.

\section{Conclusion}

1. Service quality has a positive and significant effect on patient satisfaction, meaning that the higher the quality of service, it will be followed by an increase in patient satisfaction or vice versa. This means that there is optimal service quality, so patient satisfaction will be created by itself.

2. Service facilities have a positive and significant effect on patient satisfaction, meaning that the patient's perception of the availability of complete facilities will be higher and will be followed by an increase in patient satisfaction. This means that complete service facilities are available and the benefits of patients can be obtained

3. The value of the tariff has a positive and significant effect on patient satisfaction, meaning that high or low value of the rate (price) offered will affect patient satisfaction.

4. Service quality has a positive and significant effect on patient interest, meaning that the higher the quality of service, an increase in patient interest or vice versa will be followed. This means that the quality of service is optimal, it will increase patient interest by itself.

5. Service facilities have a positive and significant effect on patient interest, meaning that the patient's perception of the availability of more sophisticated and complete complete facilities will be followed by an increase in patient interest. This means that complete 
service facilities are available and can be obtained by the patient, so it will create patient interest by itself.

6. The value of the tariff has a positive and significant effect on patient interest, meaning that the high or low value of the rate offered affects the patient's interest in undergoing treatment.

7. Patient satisfaction has a positive and significant effect on patient interest, meaning that high or low patient satisfaction with the previous treatment will affect the patient's interest in undergoing further treatment.

\section{References}

Adiwijaya, S., et al. (2018). Empowerment Pattern for Thalasemi Patients in Dr. Soetomo Hospital Surabaya (Study of the Association of Parents with Thalassemia Indonesia, Surabaya). Budapest International Research and Critics Institute-Journal (BIRCIJournal), Vol I, No 4, Page: 289-298

Assael Henry, Consumer Behavior 6th Edition. New York : Thomson Learning: 2001

B. Ibrahim, B. 1997.“TQM, Panduan Untuk Menghadapi Pasar Global” Jakarta : Penerbit Djambatan, 2000

Fandy Tjiptono, Strategi Pemasaran, Yogyakarta : Andi Offset, 2000

J. John, Patient Satisfaction: The Impact of Past Exdperience, JHCM.Vol 12.No. 3. pp 5664, 1992

Kotler, Philip \& Keller, Marketing Management, United States: Pearson Education 15th edition, 2016

Lovelock, Christopher \& Lauren K. Wright, Manajemen Pemasaran Jasa, Jakarta: PT. Macanan Jaya Cemerlang, 2007

Munawar, Beku, S dan Maidin, A, Rasionalisasi Tarif Rawat lnap Rumah ' Sakit melalui Analisis Biaya Satuan, Kemampuan dan Kemauan Pasien Membayar (Studi Kasus di Rumah Sakit Umum Kabupaten Majene Jurnal Administrasi Kebijakan Kesehatan, Vol. 1, No. 2, 2003), hal. 88

Rambat Lupiyoadi, Manajemen Pemasaran Jasa:Berbasis Kompetensi. Jakarta: Salemba Empat Edisi ke 3, 2013

Sutantio, Magdalena, Studi Mengenai Pengembangan Minat Beli Merek Ekstensi Studi Kasus Produk Merek Sharp di Surabaya Jurnal Sains Pemasaran Indonesia Vol. III No. 3, 2004

Setya Enti Rikomah, Farmasi Rumah Sakit, Yogyakarta: CV Budi Utama, Oktober 2017

Wahyuni, N. S., Fauzia, R. (2020). The Relationship between Social Supports with Nursing Employee Attachment at Dr. R.M. Djoelham Hospital Binjai. Budapest International Research and Critics Institute-Journal (BIRCI-Journal), Vol 3, No 2, Page: $816-828$ 